\title{
The RePublic AND THE MONARCHY IN CONFRONTATION: THE Portuguese Civil War on the Galician border (1911-1912) A República e a Monarquia em confronto: a Guerra Civil portuguesa na raia galega $(1911-1912)^{\star}$
}

Luís Miguel Moreira

\section{Universidade do Minho}

Immgeo@gmail.com

\section{Fecha recepción 13.07.2018 / Fecha aceptación 18.02.2019}

\section{Resumen}

La progresiva radicalización ideológica del régimen republicano, instaurado en Portugal en octubre de 1910, provocó una oposición conservadora y monárquica que se organizó en el exilio, sobre todo en el sur de Galicia. Entre octubre de 1911 y junio de 1912, estacionados en varios pueblos y villas gallegas en la raya con Portugal, los monárquicos hicieron dos incursiones en territorio portugués - el primero en Vinhais y el segundo en Chaves- con el fin de fomentar la rebelión contra régimen instaurado. Sin embargo, las tropas republicanas, más

\begin{abstract}
The ideological radicalisation of the republican regime, established in Portugal in October 1910, gave rise to the forming of a conservative and monarchical opposition in exile, in the south of the Spanish historic region of Galicia. Between October 1911 and June 1912, from several Galician villages not far from the Portuguese border, the monarchists made two incursions into the north of the country - the first to Vinhais and the second to Chaves - with the aim of fuelling popular uprisings and a military rebellion
\end{abstract}

\footnotetext{
* Trabalho realizado no âmbito do projeto CSO2015-65301-P (MINECO/ FEDER).
} 
numerosas y mejor equipadas, vencieron todos los combates. En la época, este episodio de guerra civil mereció amplia cobertura periodística, particularmente por la prensa afecta al régimen republicano. Los mapas y las fotografías de la frontera fueron ampliamente utilizados para localizar e ilustrar los acontecimientos. En este texto, pretendemos reconstituir estos movimientos, proponiendo una lectura geográfico-histórica de la raya luso-gallega, en el contexto de este episodio.

\section{Palabras clave}

República portuguesa; incursiones monárquicas; raya galaico-portuguesa; cartografia propaganda against the new regime. However, the Republican troops, more numerous and better equipped, won all the battles. At the time, this episode of civil war received extensive journalistic coverage particularly from the newspapers close to the republican regime. Maps and photographs of the border were widely used to locate and illustrate the events. From the historic-geographical perspective of the Portuguese-Galician border, this paper reconstitutes these movements in the broader historical context.

\section{Key words}

Portuguese Republic; monarchical incursions; Portuguese-Galician border; propaganda maps. 


\section{Introdução}

O século XX português ficou marcado pela mudança de regime ocorrida em 1910, quando a revolução republicana terminou com quase 800 anos de regime monárquico. No entanto, durante o período da Ditadura Nacional (1926-1932) e do Estado Novo (1933-1974) que lhe seguiu, alguns dos valores defendidos pela República, como democracia, constitucionalismo ou parlamentarismo - já para não mencionar os mais radicais, liberdade, igualdade e fraternidade- foram considerados perigosos. Muitos republicanos, tidos como reacionários, foram presos e/ou exilados do país, enquanto os monárquicos foram reabilitados. A História de Portugal ensinada durante o Estado Novo, não englobava os acontecimentos das primeiras três décadas do século XX.

Assim, foi só após a instauração da III República, a partir de 1976, que se recuperou e valorizou a memória e os valores constitucionais republicanos ${ }^{1}$. Mais recentemente, aquando das comemorações do I Centenário da Implantação da República (2010), foi publicada ou republicada, uma grande quantidade de bibliografia sobre este episódio da História recente de Portugal. Contudo, quando se procede a uma análise bibliográfica, verifica-se que, com exceção do período da I República (1910-1926), o episódio das «Incursões Monárquicas», enquanto movimento contrarrevolucionário, não mereceu uma atenção especial por parte da maioria dos autores. Curiosamente, os maiores contributos para a compreensão deste evento vieram de autores espanhóis, como Hipólito de la Torre Gómez e Sílvia Enrich Marcet, mas apresentando-o na ótica da História Diplomática, Política e Militar.

Assim, neste trabalho, propomos uma leitura das «Incursões Monárquicas» na perspetiva da Geografia Histórica. Procedemos a uma revisão de algumas das principais fontes bibliográficas coevas, na tentativa de reconstituirmos cartograficamente as principais movimentações militares (a maior lacuna identificada na revisão bibliográfica), e introduzindo

1. Sobre este assunto, ver A. Silva, "A Escrita (vária) da I República Portuguesa”, Ler História, 38, 2000, 197-254. 
uma leitura de fontes iconográficas, como fotografias, desenhos e, sobretudo, mapas publicados na imprensa periódica portuguesa afeta ao regime republicano, concretamente no diário A Capital, nos anos de 1911-1912.

Começamos por apresentar o contexto geral que levou à revolução republicana de 1910, bem como, a preparação da contrarrevolução monárquica. As duas incursões serão analisadas separadamente, apresentando-se, primeiro, uma reconstituição dos seus itinerários e, posteriormente, uma leitura a partir dos mapas divulgados pelos periódicos.

\section{As origens do movimento republicano português}

O movimento republicano português surgiu no decorrer da segunda metade do século XIX, ainda que só tenha adquirido uma maior expressão social a partir da década de $1890^{2}$. Constituía uma corrente de pensamento de inspiração neoiluminista e positivista, e que herdou uma tendência jacobina e anticlerical, não só a partir da experiência da Revolução Francesa de 1789, como também do Liberalismo Constitucional português, que emergiu da Revolução Liberal de $1820^{3}$.

Para a sua génese e posterior evolução, muito contribuíram as inúmeras revoltas e revoluções de carácter popular, socialistas e republicanas que ocorreram na Europa, desde logo, as revoluções de 1848, a implantação da III República em França, em 1871, a I República espanhola em 1873-1874 e, sobretudo, a revolução republicana no Brasil, em 1889, acontecimento que, dados os laços históricos, sociais e culturais em comum, teve uma enorme repercussão na sociedade portuguesa ${ }^{4}$.

O movimento republicano português era então apoiado, essencialmente, pela elite académica e maçónica do país, que aspirava a uma mudança de regime de forma pacífica e "democrática", tida como natural no quadro do progresso humano, tal como o entendia o Positivismo comtiano. Neste sentido, a criação do Partido Republicano Português, em 1883, congregando diferentes organizações republicanas, representava o culminar desta aspiração. No entanto, seria um acontecimento diplomático a espoletar um forte sentimento antimonárquico na sociedade portuguesa, rapidamente ampliado pela propaganda republicana. Tratou-se do Ultimatum britânico de 1890.

Efetivamente, pela Conferência de Berlim, em 1885, as potências coloniais europeias (mas em especial a França e a Alemanha), reconheceram a Portugal o direito de exploração

2. R. Ramos, "Ideias de República em Portugal até ao Século XIX: algumas observações", Polis: Revista de Estudos Jurídico-Políticos, 13, 16, 2007, 55-80.

3. F. Catroga, "O Republicanismo Português (Cultura, história e política)", Revista da Faculdade de Letras - História, III, 11, 2010, 96-97.

4. S. Brancato, "A Repercussão em Portugal da Implantação da República no Brasil", en A. Homem, A. Silva e A. Isaía (coord.), Progresso e Religião: a República no Brasil e em Portugal 1889 - 1910, Coimbra, 2007, 89-107 e E. Gonçalves, "Ressonâncias em Portugal da implantação da República no Brasil (1889-1895)", en A. Homem, A. Silva e A. Isaía (coord.), Progresso e Religião: a República no Brasil e em Portugal 1889 - 1910, Coimbra, 2007, 109-129. 
dos territórios africanos compreendidos entre a costa atlântica de Angola e o litoral índico de Moçambique, um imenso território onde a presença portuguesa era, ainda, muito incipiente $^{5}$. Esta aparente vitória diplomática correspondia a uma velha aspiração portuguesa, materializada em várias viagens de exploração ao interior de África e difundida através do célebre "Mapa Cor-de-Rosa" ${ }^{6}$.

Assim, foi num ambiente de profunda exaltação patriótica que o governo se preparava para tomar posse destes territórios coloniais. Contudo, esta intensão colidia diretamente com os interesses coloniais britânicos, em especial com os da Companhia Britânica da África do Sul, de Cecil Rhodes, e do seu plano de ligar as cidades do Cabo, na África do Sul, ao Cairo, no Egipto, por uma linha de caminho-de-ferro, pois os territórios portugueses na África Austral dividiam em dois os do império britânico.

Em 11 de janeiro de 1890, o governo Britânico liderado por Lord Sulisbury entregava um ultimato a Portugal, exigindo o total abandono daqueles territórios por parte das forças expedicionárias portuguesas, sob ameaça de um conflito. Este acontecimento causou a indignação generalizada da sociedade portuguesa e motivou fortes protestos populares, alimentados por um sentimento antibritânico. Uma vez que o governo não teve capacidade diplomática para congregar apoios para a sua causa, aceitou e cumpriu as exigências britânicas, o que causou um mal-estar que, rapidamente, foi aproveitado pela propaganda republicana para transformar a insatisfação popular em protestos antimonárquicos ${ }^{7}$.

Este clima de contestação crescente culminou com a revolta na cidade do Porto, no dia 31 de janeiro de 1891, tendo sido proclamada a República, ainda que por poucas horas, antes de a revolta ter sido sufocada militarmente pela Guarda Municipal ${ }^{8}$. As condições para a mudança de regime ainda não estavam reunidas, mas, em todo o caso, demonstrava-se que a República só seria implantada por uma ação de rebelião e com recurso à violência, e não pela via democrática?.

Assim, nos últimos anos do século XIX, multiplicaram-se os comícios, as palestras e a propaganda do Partido Republicano, que, a seu tempo, fará eleger vários deputados ao Parlamento. Simultaneamente, a fação mais radical e violenta do movimento republicano, corporizado na sociedade secreta "Carbonária», intensificou as ações de violência e de terror contra as instituições monárquicas, que se mostravam, progressivamente, mais frágeis e incapazes de lidar com a crescente contestação nas ruas e nas Cortes, onde os deputados republicanos exerciam uma ação de permanente agitação contestatária.

O clímax desta situação foi atingindo quando, após uma campanha bombista, a Carbonária conseguiu assassinar o Rei e o Príncipe Herdeiro, num atentado perpetrado em Lisboa,

5. H. Raposo, História Politicamente Incorrecta de Portugal Contemporâneo, Lisboa, 2013, 93-95.

6. Veja - se este ambiente em R. Martins, D. Carlos, História do seu reinado, Lisboa, 1930, 165-246.

7. N. Teixeira, "Política externa e política interna no Portugal de 1890: o Ultimatum Inglês", Análise Social, XXIII (98), 1987, 687-719.

8. Sobre este movimento, veja-se J. Chagas e Coelho, História da Revolta do Porto de 31 de Janeiro de 1891, Porto, 1901 ou F. Sousa, O Porto e a revolta do 31 de Janeiro, Porto, 1977.

9. F. Catroga, “O Republicanismo..., loc. cit., 97. 
no dia 2 de fevereiro de 1908. Acelerava-se, deste modo, a queda da Monarquia, o que viria a acontecer em outubro de $1910^{10}$. Efetivamente, entre os dias 3 e 4 daquele mês, em Lisboa, decorreu uma revolta de cariz popular, com a clara intenção de derrubar o regime monárquico.

Numa primeira fase, logo após a morte dos dois principais chefes revolucionários, a revolta parecia condenada ao fracasso, pois o Exército não havia aderido à revolta e a Guarda Municipal permanecia fiel ao Rei. Contudo, à medida que a posição dos revoltosos se consolidou, e face à imobilização das forças fiéis à monarquia, incapazes de os desalojar, um maior número de civis se juntaram aos revoltosos, desequilibrando a balança das forças em confronto. Por sua vez, as tripulações dos navios de guerra da Marinha fundeados no rio Tejo decidiram tomar partido pela revolução e iniciaram um bombardeamento da cidade de Lisboa, atingindo os principais símbolos da instituição monárquica, nomeadamente, o Palácio Real. A partir daqui tudo se precipitou, o Rei e o Governo fugiram da capital, tendo a Família Real embarcado no seu iate em direção a Gibraltar e, posteriormente, rumando paro o exílio em Inglaterra.

O único esforço de resistência militar monárquica contra a revolta foi liderado pelo capitão Henrique de Paiva Couceiro, herói das campanhas coloniais africanas, mas dada a diminuta força sob seu comando, foi impotente para evitar a vitória republicana ${ }^{11}$. Na manhã do dia 5 de outubro de 1910, na varanda da Câmara Municipal de Lisboa, era proclamada a República Portuguesa ${ }^{12}$.

Fora dos principais centros urbanos, a mudança de regime foi acolhida pela população com alguma indiferença e mesmo em alguns setores da sociedade tradicionalmente ligados à causa monárquica, a mudança foi aceite com expectativa e alguma benevolência.

Pouco tempo após a entrada em funções do governo provisório da República, começaram as primeiras divisões e dissensões entre os membros do Partido Republicano e que levou à formação de três novos partidos políticos, com destaque para a fação mais radical liderada por Afonso Costa, que contava com o apoio da Carbonária para assumir o controlo da sociedade. Começaram, assim, as perseguições e vinganças políticas e religiosas, as destituições de cargos públicos, especialmente nas forças policiais e militares, os julgamentos sumários e generalizando-se a violência nas ruas, direcionada para todos aqueles que, de forma fundamentada ou não, não partilhavam dos ideais revolucionários ou estavam associados à monarquia ${ }^{13}$.

10. Ver o contexto político que antecedeu a queda da Monarquia em A. Pires, "As letras de uma revolução: a implantação da república em Portugal a 5 de outubro de 1910”, Estudos Históricos, 30, (61), 2017, 331354.

11. C. Dias, Do Desafio à Debandada, vol. I, Lisboa, 1912, 49-72.

12. Para acompanhar todo o processo que culminou com a implantação da I República, e desta até ao seu fim em 1926, recomenda-se a leitura de: R. Ramos, “A Segunda Fundação (1890-1926)”, en J. Mattoso (dir.) História de Portugal, ed. revista e actualizada, Lisboa, 2001.

13. Sobre os anos conturbados da Primeira república, ver J.N. Pinto, Nobre Povo - Os Anos da República, Lisboa, 2010. 
Foi neste contexto que, a partir de janeiro de 1911, alguns membros da aristocracia portuguesa, assim como inúmeros simpatizantes da causa monárquica (entre eles, muitos elementos do clero), decidiram partir para o exílio, encontrando nas principais localidades do sul da Galiza o refúgio ideal.

Nesta fase, alguns monárquicos já esboçavam organizar uma contrarrevolução, mas a vigilância carbonária tornava tudo mais difícil e os militares ainda não mostravam sinais de descontentamento com a República. Por sua vez, o Rei, exilado em Inglaterra, não dava mostras de poder ou querer patrocinar um levantamento que poderia arrastar o país para uma guerra civil ${ }^{14}$. Refira-se, também, que nem todos os monárquicos pretendiam um regresso ao passado recente, e não se mostravam dispostos a fazer regressar ao trono D. Manuel II. Apesar de estar em preparação um comité central contrarrevolucionário, faltava um líder carismático capaz de congregar as diversas vontades ${ }^{15}$.

\section{Paiva Couceiro, o paladino da Monarquia}

O nome mais consensual para liderar este movimento era o do capitão de Artilharia Henrique Mitchel de Paiva Couceiro, militar que havia sido elevado à categoria de "Herói da Pátria" pelos seus feitos nas campanhas de ocupação colonial em Angola e em Moçambique, durante a década de 1890. O capitão Couceiro integrava um conjunto de oficiais do Exército, conhecido como "os africanistas", que partilhavam ideais monárquicos tradicionalistas e antiliberais, e que propunham uma renovação do regime de tendência ditatorial ${ }^{16}$.

Em todo o caso, entre os dias 3 e 5 de outubro de 1910, foi o único oficial que, perante a imobilidade geral, desenvolveu ações de resistência contra a revolta em curso, com o intuito de defender a Coroa e que lhe valeu, pelo menos no imediato, o reconhecimento dos seus oponentes. Assim, nos meses seguintes, após terem negado o seu pedido de demissão, as autoridades republicanas procuraram convencê-lo a manter-se no ativo, obedecendo às novas chefias.

Perante a sua recusa em abraçar os ideais republicanos e tendo mesmo apresentado um ultimato ao governo provisório, exigindo a realização de um plesbicito para que a sociedade se pronunciasse sobre a mudança de regime, a República emitiu um mandado de captura, que só não surtiu efeito porque Paiva Couceiro, atempadamente avisado, escapou em direção a Vigo, na Galiza, onde, em março de 1911, foi recebido como o chefe militar que o movimento restauracionista necessitava ${ }^{17}$.

A partir de então, a organização monárquica preparou-se para, a partir do exterior, instigar um levantamento geral do País de carácter restauracionista, muito embora Couceiro

14. Sobre as movimentações monárquicas contra a República, ver M. Santos, A contra-revolução na I República: 1910-1919, Coimbra, 2010.

15. M.T. Mello, Memórias da Condessa de Mangualde, 2a ed., Lisboa, 2002.

16. Uma biografia deste militar português pode ser consultada em V. Valente, Um Herói Português - Henrique Paiva Couceiro (1861-1944), Lisboa, 2006.

17. C. Dias, Do Desafio ..., op., cit. 
reivindicasse um movimento politicamente neutro, de modo a permitir a realização de um referendo que, na sua ótica, legitimaria o regresso do regime monárquico.

Ainda que, maioritariamente concentrados em Vigo e em Tui, a comunidade portuguesa expatriada na Galiza também estava presente noutras localidades do Sul daquela região espanhola, alargando a sua rede de contactos, de forma a poder constituir uma base de apoio operacional para uma previsível futura ação (para)militar sobre a fronteira portuguesa.

Enquadrados por um diminuto número de oficiais militares que tinham abandonado (ou a isso obrigados) o Exército, os voluntários que constituíam o "exército" monárquico, iniciaram os preparativos para uma incursão contra a República. Contando com o apoio da fação Miguelista (ou Legitimista ${ }^{18}$ ), os conspiradores portugueses procuraram obter apoios internacionais, tanto em termos financeiros como em armamento, munições e até tentaram adquirir alguns navios de guerra capazes de ameaçar, pelo menos, a cidade do Porto e o Norte do País.

Nestes primeiros meses de preparativos as autoridades policiais na Galiza, muitas vezes contando com o apoio voluntário de republicanos locais, conseguiram localizar e apreender vários carregamentos de armas e de munições destinados aos portugueses ${ }^{19}$. Beneficiando do apoio dos partidários Carlistas, dos políticos, dos aristocratas e dos membros do clero da Galiza, que exerciam a sua influência junto das autoridades civis e militares, os contrarrevolucionários portugueses entregavam-se a atividades conspirativas ${ }^{20}$.

Perante este cenário, que constituía uma séria ameaça à sua estabilidade política e social, a República decidiu atuar em duas frentes: externamente, os diplomatas portugueses esforçaram-se por obter o reconhecimento das principais potências europeias, em particular, o do Reino Unido. Na frente interna, o governo provisório procurou legitimar o novo regime, acelerando o processo de formação da Assembleia Constituinte, capaz de aprovar uma Constituição republicana, o que veio a acontecer em agosto de $1911^{21}$.

Simultaneamente, o governo decretou uma mobilização militar, sobretudo das unidades fiéis ao regime e estacionadas em Lisboa, enviando-as para os distritos do Norte do país, especialmente Viana do Castelo e Braga. A fronteira do rio Minho passou a ser vigiada por militares da Marinha, apoiados por duas canhoneiras e um cruzador, enquanto a vigilância da raia seca, sobretudo o Planalto de Castro Laboreiro, o Lindoso, a Portela do

18. A Guerra Civil portuguesa (1828-34) opôs o partido Absolutista, liderado pelo então rei (consorte) de Portugal D. Miguel de Bragança, ao partido Liberal, liderado pelo seu irmão mais velho, D. Pedro de Bragança, ex-Rei de Portugal e ex-Imperador do Brasil. Após dois anos de confrontos militares, a guerra terminou com a vitória do partido Liberal e a expulsão definitiva de Portugal de D. Miguel e dos seus seguidores. Este ramo da família Bragança, denominado Legitimista, uma vez no exílio, não deixou de reivindicar o Trono de Portugal, aguardando com expectativa uma possibilidade de regresso que agora se apresentava na forma de oposição e tentativa de derrube do regime republicano. Nesta primeira fase da luta antirrepublicana, o pretendente D. Miguel II e o seu herdeiro D. Duarte, envolveram-se pessoalmente neste movimento, mais até que o próprio monarca exilado D. Manuel II.

19. Notícias publicadas no jornal A Capital, nos dias 16 e 26 de junho de 1911.

20. Sobre o ambiente político e diplomático entre Portugal e Espanha nestes anos de contrarrevolução, ver H. Torre Gómez, Conspiração contra Portugal, 1910-1912, Lisboa, 1978.

21. V. Engrossa, Uma Diplomacia Estratégica: José Relvas em Madrid (1911-1913), Lisboa, 2016. 
Homem e a Veiga de Chaves, ficou entregue às unidades de reforço do Exército enviadas de Lisboa. Nesta altura, a imprensa republicana noticiava que as movimentações "couceiristas" ameaçavam a região de Entre Douro e Minho, mas as autoridades militares estavam preparadas para os enfrentar.

Todas estas movimentações foram acompanhadas de perto pela imprensa periódica - em especial pelo jornal republicano A Capital - para efeito de propaganda a favor do regime. De forma a contextualizar geograficamente as notícias, os jornais publicavam mapas que ajudavam os leitores a localizarem os acontecimentos ${ }^{22}$. O primeiro mapa foi publicado na edição do dia 29 de junho de 1911, e acompanhava uma notícia intitulada "Á Fronteira", destacando-se o território da fronteira do Minho compreendido entre a serra da Peneda e o rio Lima, visto ser aí que as autoridades republicanas esperavam a incursão monárquica. $\mathrm{O}$ segundo mapa foi publicado no dia 9 de julho com a notícia "O Plano de Couceiro", e de novo se figurava o território fronteiriço do Alto Minho, dando-se conta das intenções couceiristas de conquistar Braga e sublevar os concelhos circunvizinhos. Assim, o mapa, que figura o território compreendido entre o rio Minho, a norte e o rio Cávado, a sul, mostra as principais vias de comunicação rodo e ferroviárias dos distritos de Viana do Castelo e de Braga, assinalando os prováveis pontos de entrada dos incursionistas monárquicos na Galiza.

$\mathrm{Na}$ sua edição de 6 de setembro, o jornal A Capital destacava a notícia "Lobos no povoado", onde assegurava que a República dispunha de forças suficientes para derrotar os monárquicos. O mapa que a acompanha figura toda a faixa fronteiriça entre o norte de Portugal e o sul da Galiza, identificando-se os lugares onde se registaram atividades contrarrevolucionárias, bem como os lugares por onde se esperava a anunciada incursão couceirista: "o mapa indica as povoações da Galiza por onde estavam distribuídos os conspiradores e [palavra ilegível] da fronteira junto da qual se encontram desde ontem concentrados. Os pontos marcados como entradas prováveis de forças realistas são o rio Minho, junto de Monção, Tibo, quase em frente a Entrimo, Lindoso, na margem do rio Lima, Portela do Homem e raia seca de Tourém até Feces de Abajo" (Figura 1).

Aproveitando esta enorme presença militar na região de Entre Douro e Minho, tradicionalmente conservadora e pouco recetiva aos ideais republicanos, o governo provisório promoveu ações de propaganda como comícios e palestras conduzidos por militares, junto das populações ${ }^{23}$.

Entretanto, oficializando-se a eleição do Presidente da República e do governo, a que se seguiu o reconhecimento internacional do regime, esperava-se que as autoridades espanholas perseguissem e aprisionassem os contrarrevolucionários, pelo que, logo no início de setembro de 1911, o enorme dispositivo militar sobre a fronteira foi desmobilizado, até por-

22. A utilização de mapas propagandísticos por parte da imprensa portuguesa era relativamente frequente e habitual, desde, pelo menos, a questão do ultimatum britânico, em 1890. O auge seria atingido aquando da Primeira Guerra Mundial. Sobre este assunto, ver L. Moreira, “A Guerra na Europa (1914/1918): Cartografia e Opinião Pública”, en Actas do VIII Colóquio Ibérico de Geografia, vol. I, Lisboa, 1999, 236 - 244.

23. A imprensa afeta à República fez uma ampla cobertura fotojornalística destas ações de propaganda. Veja-se os números da Ilustração Portuguesa entre julho e setembro de 1911. 

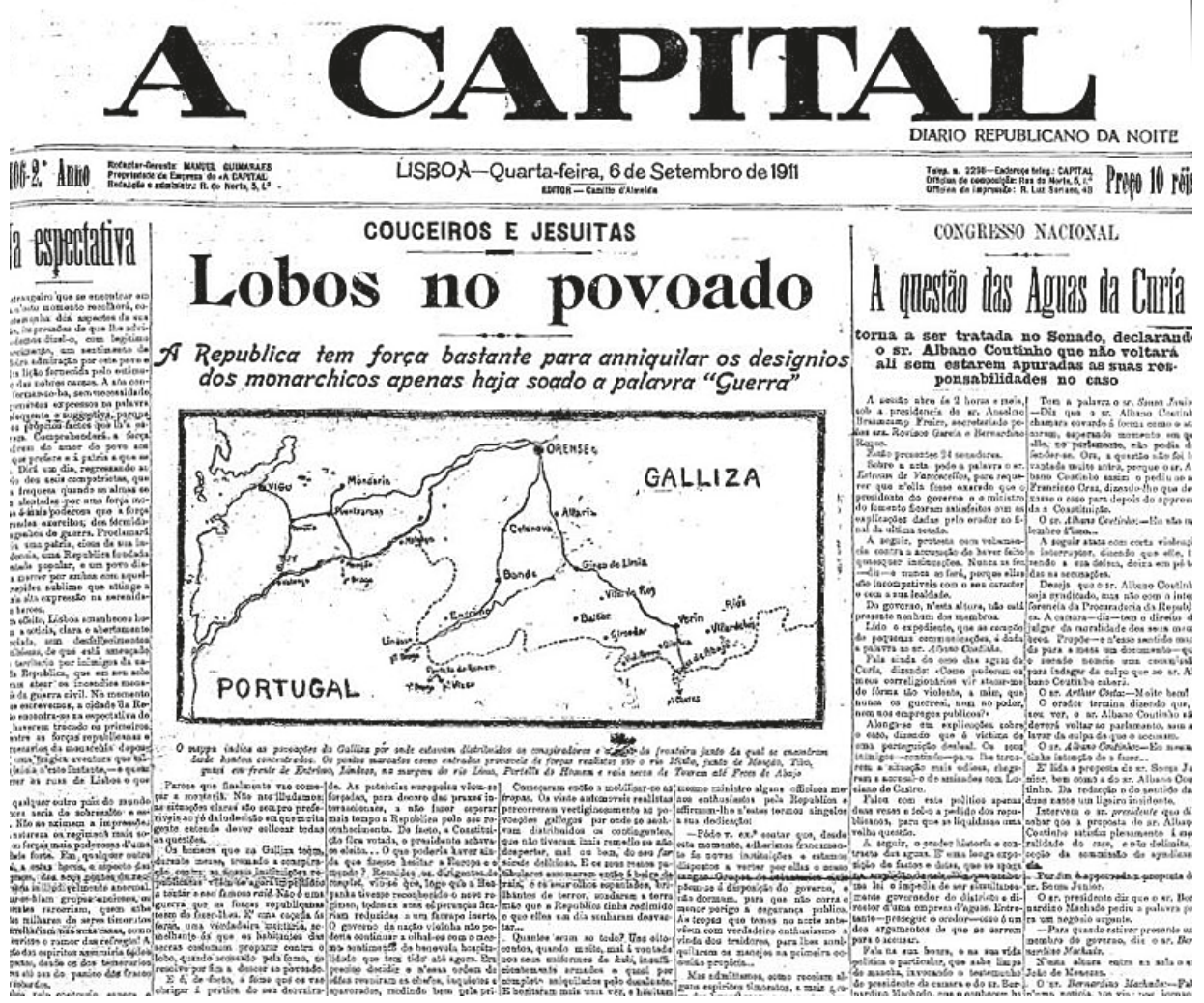

Figura 1. O mapa que acompanha a notícia "Lobos no povoado", pretendia demonstrar que os republicanos mantinham a fronteira com a Galiza vigiada e os movimentos monárquicos controlados. Fonte: A Capital, 6 de setembro de 1911.

que representava um grande encargo para o Erário ${ }^{24}$. Em todo o caso, a fronteira continuou a ser vigiada, embora de uma forma mais modesta e com efetivos claramente em número insuficiente, como se veio a verificar posteriormente. Assim, este plano de defesa militar da fronteira terrestre previa que vários pequenos destacamentos ocupassem posições estratégicas, vigiando os principais itinerários da Província de Trás-os-Montes, mas encontrando-se isolados uns dos outros e em inferioridade numérica face aos possíveis invasores. O mapa da Figura 2 reconstitui este dispositivo militar e, ao mesmo tempo, figura o principal teatro de operações desta guerra civil.

24. S. Enrich Marcet, Las tentativas de Restauración Monárquica Portuguesa en relación com España 19111912, 2004, 197-202. 


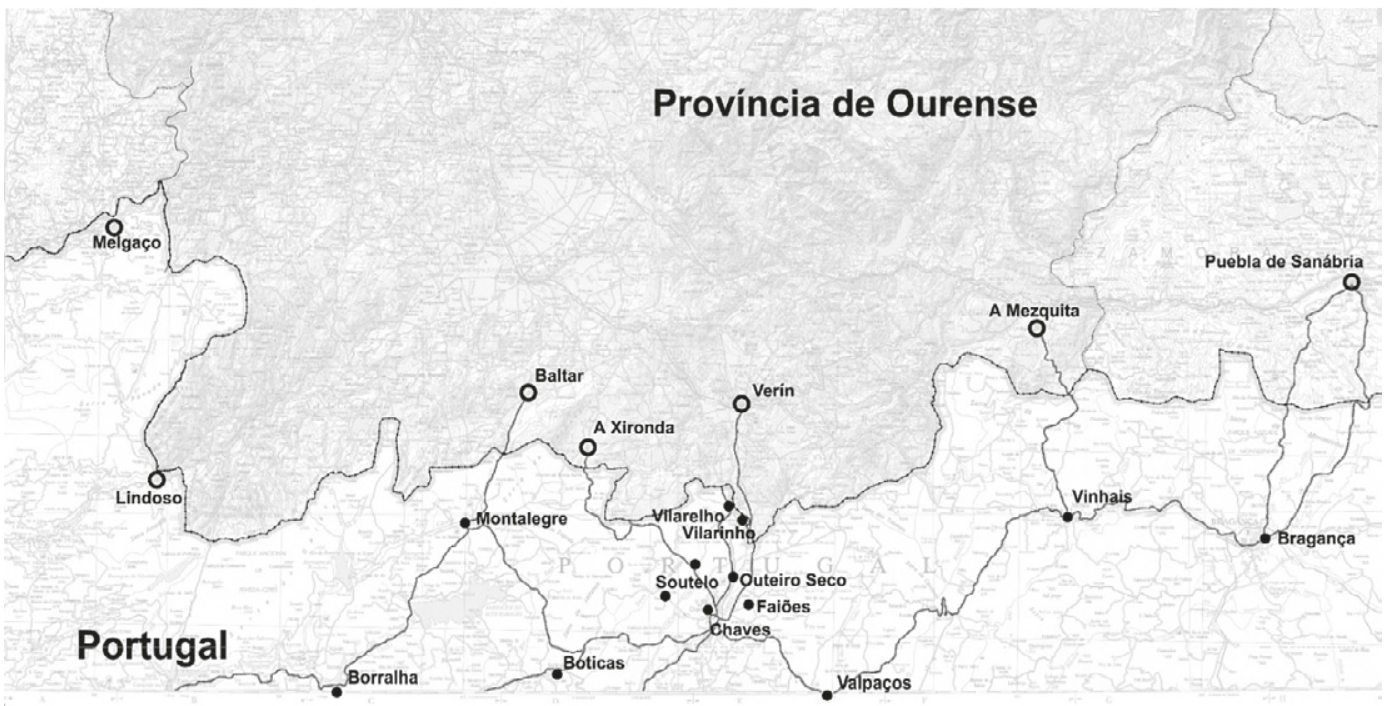

Fonte: S. Enrich Marcet, Las tentativas de Restauración Monárquica Portuguesa en relación com España 1911-1912, 2004

Localidades com destacamentos do Exército português

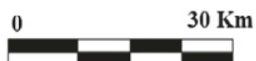

Figura 2. Dispositivo militar para a vigilância da raia seca de Trás-os-Montes contra as incursões monárquicas, em setembro/outubro de 1911.

Esta foi a oportunidade que os conspiradores necessitavam, até porque já estavam a ser pressionados pelas autoridades da Galiza que, a instâncias do governo central, em Madrid, pretendiam transferir os portugueses para províncias espanholas mais afastadas da fronteira. Assim, Paiva Couceiro ordenou aos diferentes grupos que se pusessem em marcha para leste, em direção à Província de Zamora.

Os conspiradores iniciaram a sua marcha em Sarreaus, a 17 de setembro de 1911. Ao longo de 18 dias de caminhadas por itinerários pouco frequentados, de forma a iludir a vigilância da polícia local e dos espiões republicanos, percorreram sucessivas etapas através das localidades de Albarelhos, Ábedes, Fumaces, Vilardevós, S. Lourenzo (de Pentes), A Gudiña, A Caniza, A Canda e Las Hedradas, já na Província de Zamora, onde chegaram no dia 28 de setembro ${ }^{25}$. Finalmente, agruparam-se em várias povoações leonesas situadas a norte da fronteira de Bragança: em Villanueva de la Sierra, ficaram acantonados os homens da inexistente bateria de artilharia; em Las Hedradas, a $3^{\text {a }}$ companhia; em A Canda, os Serviços de

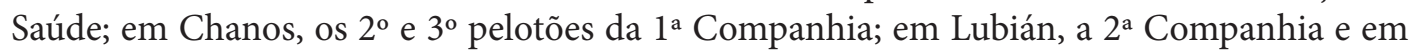
Puebla de Sanabria, o $1^{\circ}$ Pelotão da $1^{\text {a }}$ Companhia ${ }^{26}$.

25. M.Valente, A Contra-Revolução Monarchica, 1912, 153-154.

26. M. Valente, A Contra-revolução..., op. cit., 154-156. 
Aqui esperaram alguns dias pelo armamento e, finalmente organizados numa coluna composta por cerca de 950 indivíduos, partiram da Portela do Padornelo, mal equipados e escassamente armados e municiados (apenas 250 homens iam armados), para uma incursão na fronteira de Portugal, viajando de noite através da serra de la Gamoneda, também, por vezes, denominada de serra da Teixeira.

Importa referir que este movimento estaria a ser coordenado com um levantamento ou pronunciamento militar interno - sobretudo nos distritos do norte do país - a que se seguiria, assim se esperava, a adesão das populações rurais. Pese embora algumas tentativas de movimentações militares na cidade do Porto, prontamente controladas pelas autoridades republicanas e de alguns distúrbios populares naquele distrito, a esperada sublevação interna redundou num fracasso ${ }^{27}$.

Tudo indica que o objetivo principal traçado por Paiva Couceiro seria ocupar de surpresa a cidade de Bragança. No entanto, os guias que conduziram a coluna perderam-se, forçando-a a uma demora de dois dias nas imediações da aldeia de Tejera, bem próximo da fronteira portuguesa, tendo sido a sua presença sentida por membros da Guarda Fiscal que alertaram as autoridades militares de Bragança ${ }^{28}$.

Deste modo, na madrugada do dia 5 de outubro de 1911, os incursionistas entraram em território português mas desviaram o destino da marcha em direção a Vinhais, num percurso iniciado no interflúvio dos rios Sabor, a Este, e Tuela, a Oeste, e que os conduziu pelas aldeias de Cova da Lua, Espinhosela e Prada, nem sempre seguindo os caminhos existentes, de forma a iludir a vigilância das autoridades ${ }^{29}$.

Vinhais apenas contava com uma pequena guarnição militar composta por um destacamento de infantaria e de cavalaria com cerca de 80 efetivos que, face à aproximação da coluna de Couceiro, se retirou da povoação para ocupar uma posição mais elevada, cobrindo a estrada que partia em direção a Valpaços e a Chaves. Entretanto, o comandante deste destacamento, o capitão Viana Andrade, já havia solicitado reforços, quer a Bragança, quer a Chaves e Vila Real, mas que não chegaram. Assim, após um breve combate travado com a cabeça da coluna monárquica, decidiu retirar em boa ordem em direção a Chaves, permitindo a ocupação de Vinhais pelos incursionistas, que aí arvoraram a bandeira da monarquia constitucional e declararam restaurado, ainda que efemeramente, o regime monárquico.

Beneficiando da deficiente coordenação militar das forças republicanas, os elementos da coluna de Paiva Couceiro descansaram em Vinhais toda a tarde e princípio da noite do dia 5 de outubro, mas iniciaram uma marcha em direção à fronteira na madrugada seguinte, temendo um contra-ataque republicano. Assim, a incursão seguiu em direção norte, até à aldeia de Salgueiros. Daqui, a coluna continuou para a aldeia de Casares, situada a alguns quilómetros a Norte, bem perto da fronteira.

27. M. Santos, A Contra-revolução..., op. Cit.,123-124.

28. S. Enrich Marcet, Las Tentativas... op. cit.., 223.

29. A descrição da marcha da coluna entre Espinhosela e Vinhais, subindo e descendo vertentes abruptas, atravessando desfiladeiros e bosques de carvalhos, pode ser lida em M. Valente, A Contra-revolução..., op. cit., 154-156. 
Entretanto, o comandante do setor de defesa entre os rios Cávado e Mente, o Tenente Maia Magalhães, enviou um esquadrão de cavalaria desde Chaves para reforçar a defesa republicana de Vinhais, sob o comando do tenente Quaresma. Em Rebordelo, depois de se unir à força de infantaria comandada por Viana de Andrade, foi decidido pelos dois oficiais um contra-ataque a Vinhais, onde entraram sem resistência a 6 de outubro, restabelecendo naquela vila a autoridade republicana ${ }^{30}$.

A perseguição à coluna de Paiva Couceiro só se reiniciou no dia 7, quando um destacamento de cavalaria republicana enfrentou as forças monárquicas estabelecidas em Casares. A escaramuça durou pouco tempo e terminou com a retirada das forças militares, após terem sofrido algumas baixas. De seguida, a coluna incursionista, dirigiu-se para a aldeia de Pinheiro Velho.

Estes primeiros dias demonstraram a fragilidade e a impreparação da invasão monárquica: os principais objetivos militares falharam, primeiro a conquista de Bragança e depois a incapacidade de defender a posição de Vinhais; falhou, também, o prometido e esperado levantamento militar-populacional no Norte do país, bem como o suposto apoio naval que o movimento monárquico se esforçava por adquirir ${ }^{31}$. Assim, percebendo que as forças republicanas iriam aumentar os seus efetivos na perseguição à sua coluna e que as suas próprias forças perdiam capacidade de combate por cansaço, diminuição de efetivos por deserção, falta de víveres e de munições, Couceiro tomou a resolução de se internar na Galiza, de novo, acantonando-se na aldeia de Esculquera.

Em todo o caso, esta posição não significou o fim do movimento incursionista. Couceiro ainda alimentava a esperança de conseguir inspirar, pelo seu exemplo, as forças monárquicas em Portugal, ao mesmo tempo que aguardava a chegada dos navios. Assim, a coluna foi avançando para Oeste numa rota paralela à raia, através de sucessivas etapas, pelas povoações de Soutochão, Mourazos, A Granja, Gudín, Porqueirós, Sampaio de Araújo e, finalmente, San Martín de Araújo, na serra do Xurés, esperando aqui entrar em contacto com as forças lideradas pelo padre guerrilheiro, Júlio de Ruivães ${ }^{32}$ (Figura 3).

30. S. Enrich Marcet, Las Tentativas... op. cit. 184-264.

31. Os monárquicos consideraram a aquisição de dois navios de guerra e terão mesmo desenvolvidos esforços nesse sentido, ainda que sem qualquer resultado prático. Em todo o caso, a possibilidade de obtenção de dois couraçados alimentava a esperança monárquica na capacidade de ameaçar a presença naval da República no Norte do país e, pelo contrário, era fonte de inquietação e de medo entre os republicanos. Sobre este assunto, ver: V. Valente, Um Herói português..., op. cit. 99-105.

32. Esta opção estratégica e tática foi descrita pelo próprio Couceiro. (F. Meneses, Paiva Couceiro, Diários, Correspondência e Escritos Dispersos. Lisboa, 2011, 174-177) 


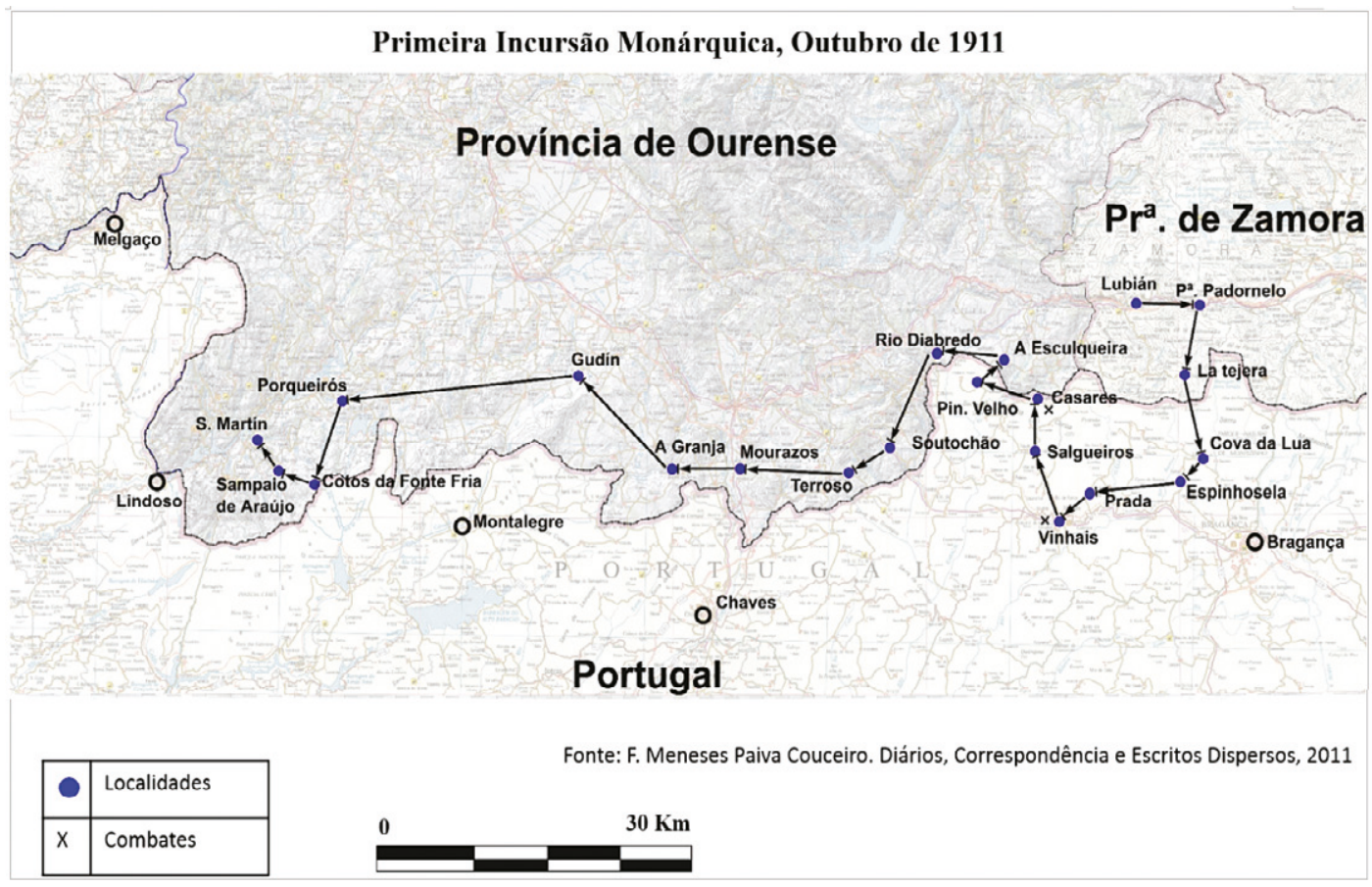

Figura 3. Trajeto da primeira incursão monárquica, reconstituída a partir do diário do Capitão Paiva Couceiro.

Ao longo deste percurso, não se verificou qualquer tentativa de levantamento interno, pelo contrário, em Chaves, local onde os couceiristas esperavam algum apoio por parte de alguns oficiais que integravam a sua guarnição, procedeu-se ao reforço de tropas fiéis ao regime que vigiavam de forma mais intensa a fronteira, controlando o movimento da coluna monárquica. Simultaneamente, fruto da pressão diplomática exercida por Portugal, as autoridades espanholas, Guardia Civil, Carabineros e Exército, também perseguiam e vigiavam os movimentos dos monárquicos portugueses, tendo mesmo efetuado uma apreensão de armas durante a noite em que Couceiro e os seus homens estavam acantonados nas imediações da serra do Gerês, sem, contudo, levarem a cabo qualquer detenção ${ }^{33}$. Estava, assim, terminada a primeira incursão monárquica, efetuada com escassos recursos, e com um elevado grau de impreparação que só poderia redundar em fracasso ${ }^{34}$.

33. É Couceiro quem descreve este episódio que põe em evidência colaboração prestada pelas autoridades espanholas na Galiza. F. Meneses, Paiva Couceiro..., op. cit., 176.

34. "Não pude deixar de estremecer ao ver a absoluta falta de preparação com que o Couceiro tinha tentado a entrada em Portugal, falta que de antemão condenava essa aventura a um inevitável fracasso" (M. T. Mello, Memórias ..., op. cit., 47). 
Refira-se que todo este movimento se fez sem um profundo conhecimento do terreno, decorrente da falta de mapas detalhados, contando com a colaboração das populações e com o apoio de guias locais, provavelmente contrabandistas e pastores ${ }^{35}$. Assim, a marcha dos incursionista ao longo de quinze dias, fez-se sob condições duras, por um terreno irregular, pedregoso e coberto de matos, atravessado por inúmeros cursos de água que dificultavam a progressão ${ }^{36}$. A isto juntava-se o mau tempo e uma logística deficiente, que deixava os homens desmoralizados, fatigados e famintos ${ }^{37}$.

Do ponto de vista dos militares republicanos, a incursão monárquica de 1911 constituiu, no mínimo, um embaraço. Mesmo após a desmobilização geral, decretada no início do mês de setembro de 1911, e o regresso às unidades de boa parte dos destacamentos avançados sobre a fronteira, as forças das $6^{\mathrm{a}}$ e 8 a Divisões Militares, respetivamente com sede em Braga e Vila Real, eram mais do que suficientes para enfrentar e derrotar os invasores, e tal só não sucedeu devido à falta de organização e de coordenação dos comandos militares. Deste modo, apesar de expectada e prevista, a incursão do dia 5 de outubro apanhou de surpresa as autoridades responsáveis pelo setor de defesa da fronteira, cuja responsabilidade recaía sobre as unidades militares de Bragança e, em parte, também de Chaves ${ }^{38}$.

35. Esta será, talvez, a razão pela qual as fontes que relatam a primeira incursão não são unânimes, nem coincidentes na indicação do percurso da coluna em retirada. Por vezes, os incursionistas perdiam as suas referências geográficas: «(...) alguém me disse ser ahi a fronteira; a árvore fazia vezes de marco. Outros asseguravam não ser assim, a fronteira corre perto, mas só passa mais acima pela linha das cumeadas...». Ver A. Queiroz, Na Fronteira (Incursões Monarchicas de 1911 e 1912), 1915, 193-194). A mesma referência se encontra no diário de Paiva Couceiro, em F. Meneses, Paiva Couceiro..., op. cit.,172. Aqui também se podem encontrar vestígios da inexistência de mapas detalhados do terreno, dado que Paiva Couceiro deixou em branco alguns espaços para, posteriormente, poder acrescentar o nome dos topónimos em falta. F. Meneses, Paiva Couceiro..., op. cit.,170. Convém frisar que, nesta altura, o único mapa de características topográficas que cobria todo o território nacional peninsular acessível ao público, era Carta Geral do Reino (também denominada Carta Chorographica do Reino), na escala 1:100 000, editada ainda durante a Monarquia, mas que não figurava o território espanhol contíguo à fronteira. A esta, juntava-se a Carta Itinerária de Portugal, que resultava de um levantamento militar nacional, à escala 1:250 000, que serviria para planeamento dos movimentos e deslocação de tropas, mas cuja escala não permitia uma análise detalhada do terreno. M.H. Dias e J.M. Rossa, Dos Serviços Cartográficos ao instituto Geográfico do exército: 75 anos de actividade a servir Portugal (1932-2007), Lisboa, 2007, 17-20 e L. Moreira, "O País «à la Carte» leitura da folha n. ${ }^{\circ} 111$ (Paredes) - Paços de Ferreira da Carta Militar de Portugal”, Oppidum, 9, 8, 2015, 196-197. Das primeiras folhas da Nova Carta Chorographica de Portugal, editada na escala 1:50 000, logo a partir do início do século XX, nenhuma abrangia esta região. Ver, M. d'Ávila e Bolama, A Nova Carta Chorographica de Portugal, 3 vols., Lisboa, 1909-1914.

36. "Em toda a extensão que vai do Douro à vertente oriental do Gerês, a fronteira é na sua maior parte raia seca. Diversos acidentes físicos, cursos de rios e ribeiras, quase sempre serras e relevos montanhosos, a assinalam. Algumas das mais altas montanhas transmontanas, como Montesinho e o Larouco, erguem as suas cumeadas no limite dos dois países". V. Taborda, Alto Trás-os-Montes. Estudo Geográfico, 2ª. ed., Lisboa, 1987, 27.

37. Veja-se a descrição do Conde de Mangualde em M. T. Mello, Memórias ..., op. cit.,.43-47.

38. A. Coimbra, Paiva Couceiro e a Contra-Revolução Monárquica (1910-1919), Braga, 2000, 104-107. 
Por um lado, a atuação do comandante militar de Bragança, em especial a partir do segundo dia de incursão, pelo facto de não ter atacado a coluna de Couceiro, nem ter enviado reforços para defender Vinhais, mereceu ampla censura, quer por parte das outras autoridades militares, como da parte da imprensa e dos setores republicanos civis mais radicais. Por outro lado, o socorro enviado por Chaves também foi incapaz de perseguir e capturar os "paivantes" em território português, assim, não só estes conseguiram passar a fronteira, como também transportaram o seu armamento. Para os militares, o fracasso da perseguição deveria ser atribuído ao mau tempo, ao mau estado dos caminhos e à escassez de recursos numa região pobre e periférica ${ }^{39}$. Como consequência imediata desta ação, alguns chefes militares, tal como o ministro da Defesa, foram substituídos e este momento foi aproveitado pelos políticos republicanos radicais para reforçar a sua influência no governo.

$\mathrm{Na}$ sequência destes acontecimentos, os jornais e, especialmente, as revistas fotojornalísticas, converteram-se numa importante fonte de propaganda política ao serviço da República, difundindo imagens das forças militares republicanas na perseguição aos incursionistas, assegurando aos leitores que a situação estava controlada pelas autoridades e os monárquicos definitivamente expulsos do país ${ }^{40}$. Mais uma vez, vários destes artigos e notícias estavam acompanhados de mapas, croquis ou esboços que os ilustravam e permitiam aos leitores contextualizarem, geograficamente, os acontecimentos descritos.

No dia 17 de outubro, no jornal A Capital, o mapa "o combate de Vinhaes", correspondia a um esboço topográfico da vila de Vinhais, figurando com curvas de nível as duas elevações ocupadas pelas duas forças em confronto e as estradas por onde ambas se retiraram depois do combate.

No dia seguinte, o jornal publicava um novo mapa, desta vez para ilustrar o Combate de Cazares: "croquis explicativo do segundo recontro entre a força republicana e os traidores". Aqui se figurava o território compreendido entre as aldeias de Landedo, Casares e Carvalhais, nas proximidades da linha de fronteira, assinalando-se, mais uma vez, as elevações ocupadas pelas forças opositoras representadas por curvas de nível. (Figura 4)

A revista quinzenal Brasil-Portugal ${ }^{41}$, na sua edição de 1 de novembro de 1911, publicou um mapa que reconstituía todo o trajeto da primeira incursão, desde as forças couceiristas em território do distrito de Bragança, até à desmobilização da sua coluna nas proximidades da serra do Gerês. O longo comentário que acompanhava o mapa, indicava que este se baseava em informação proveniente dos jornais, pelo que não era fiável e, por essa razão, não fora possível reconstituir com rigor e precisão, os itinerários da coluna monárquica. Trata-se, em todo o caso, ainda hoje, de uma das melhores reconstituições desta incursão.

39. S. Enrich Marcet, Las Tentativas... op. cit., 254-264. Aqui pode ser consultado um resumo dos relatórios e das comunicações militares sobre as operações de perseguição à coluna de Couceiro.

40. Curiosamente, uma notícia publicada pelo jornal A Capital, datada de dia 2 de outubro de 1911 - três dias antes de ter ocorrido - dava conta da consumação da incursão monárquica e da sua pronta derrota pelo Exército.

41. Desde a implantação da República, esta revista adotou uma posição editorial próxima dos ideais monárquicos. 


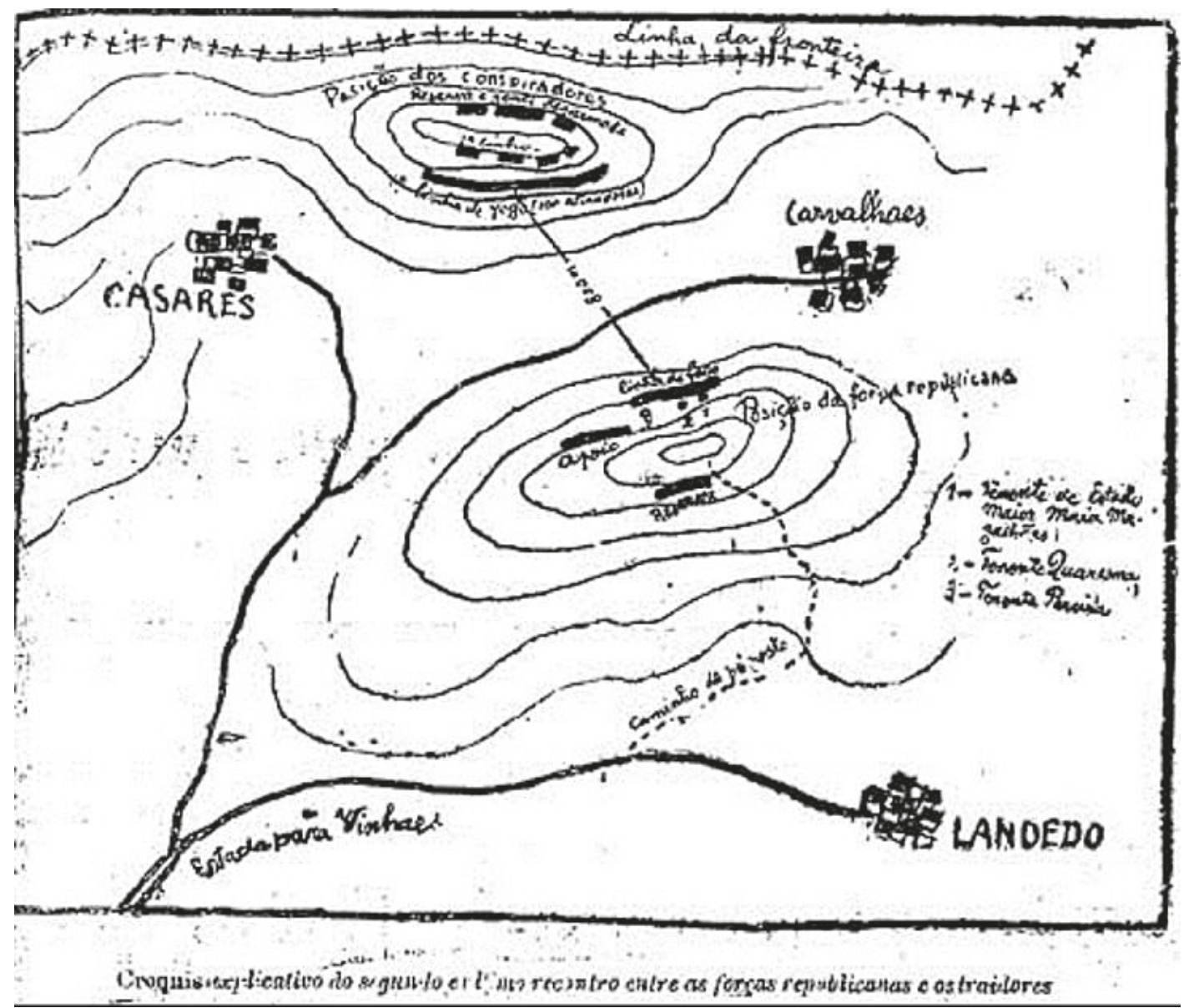

Figura 4. Mapa ilustrativo do combate de Casares, mostrando os "conspiradores” numa posição defensiva, próximos de Casares, sendo pressionados pelas forças republicanas, a partir de Landedo, para a linha de fronteira.

Fonte: A Capital, 18 de outubro de 1911.

\section{A $2^{\mathrm{a}}$ Incursão}

Quando em meados de outubro, as forças remanescentes da coluna incursionista acantonaram na vertente norte da serra do Gerês, em território galego, os seus líderes já tinham compreendido que o movimento carecia de mais e de melhor equipamento militar e de uma preparação logística mais eficaz e cuidada para ser bem-sucedida. Assim, de pronto iniciaram os preparativos para uma nova tentativa de invasão do território português e de sublevação das populações rurais. Para tal era necessário continuar a garantir os apoios políticos e assegurar o controlo das autoridades da Galiza. 
Os homens que constituíam a força armada do movimento monárquico foram distribuídos por 10 grupos que ficaram aboletados em outras tantas aldeias galegas situadas entre os vales dos rios Lima e Salas, a saber: $1^{\circ}$ grupo em Parada de Ventosa; $2^{\circ}$ grupo em Cados; $3^{\circ}$ grupo em Xendive; $4^{\circ}$ grupo em Valoiro; $5^{\circ}$ grupo em Muiños; $6^{\circ}$ grupo em Mugueimes; $7^{\circ}$ grupo em Prado; $8^{\circ}$ grupo em Xermeade; $9^{\circ}$ grupo em Porqueirós e $10^{\circ}$ grupo Cabaleiros ${ }^{42}$. Todos os grupos distavam poucos quilómetros uns dos outros e encontravam-se em permanente contacto.

Nestes primeiros meses de acantonamento, a vida quotidiana decorreu com tranquilidade. Alguns oficiais, como o Conde de Mangualde, conseguiram mesmo reunir a sua família, reconstituindo uma aparente normalidade que só era contrariada pela vigilância carbonária ou, por vezes, das autoridades policiais ${ }^{43}$. Quando os fundos da "caixa" comum não conseguiam suportar as despesas, os contrarrevolucionários tinham de assegurar os seus próprios meios de subsistência. Se para os membros aristocráticos isso não representava um grande problema, muitos outros incursionistas pagavam as suas dívidas acumuladas trabalhando à jorna na terra ${ }^{44}$.

Esta situação mudou na primavera de 1912. As pressões diplomáticas portuguesas sobre o governo espanhol, para que, cumprindo o direito internacional, não permitisse a permanência de grupos armados na fronteira portuguesa, deram resultados. As autoridades policiais galegas foram incumbidas de perseguir e internar os monárquicos portugueses em campos localizados fora da Província de Ourense. Movendo as suas influências políticas com o intuito de obter o armamento de que necessitavam ${ }^{45}$, Couceiro ordenou aos comandantes dos pelotões que iniciassem uma aparente retirada em direção à Província de Zamora, mas que usassem de todos os meios de dissimulação, fazendo-a com a maior lentidão possível de modo a limitar a marcha ao meridiano de Verín ${ }^{46}$.

Assim, entre finais de maio e o início de julho de 1912, os 10 grupos incursionistas circularam entre as aldeias de Sobradelo, Vilar de Barrio, Morgade, Carraxo, Vilameá, Laza, Sarreaus, Cortegada, Bóveda, Bresmaus, Pena, Soutelo Verde e Castrelo de Val, mantendo-se próximos da fronteira, enquanto aguardavam a ordem de concentração. Esta chegaria no início de julho, quando Madrid ordenou o envio de forças militares para auxiliarem a missão da Guardia Civil. Contudo, os monárquicos conseguiram obter um adiamento do prazo dado pelas autoridades espanholas, pelo menos, durante o tempo necessário para reunir a coluna principal, armá-la e iniciar a invasão ao território português. O ponto de reunião foi o Quartel-general no Telheiro, na lagoa de Antela ${ }^{47}$.

A segunda invasão compôs-se, na realidade, de três movimentos interdependentes, mas a topografia e a falta de comunicações acabaram por torná-los quase autónomos. Formaram-

42. J. Leitão, Couceiro, o Capitão Phantasma, Porto, 1914, 44.

43. Sobre a vida do Conde de Mangualde, ver M. T. Mello, Memórias ..., op. cit.

44. Refira-se que a permanência de várias dezenas de homens nestas aldeias do sul da Galiza, representou um forte impacto económico e social, animando os circuitos comerciais e algumas atividades relacionados com o aboletamento das "tropas".

45. Por várias vezes as autoridades espanholas haviam conseguido intercetar armamento enviado para as forças realistas. A. Coimbra, Paiva Couceiro..., op. cit., 107.

46. J. Leitão, Couceiro..., op. cit., 240-250.

47. J. Leitão, Em Marcha para a $2^{a}$ Incursão, 1914, 49-73. 
-se três colunas: uma, composta por centena e meia de homens liderados pelo tenente Victor de Sepúlveda, e que deveria desenvolver um movimento a partir do vale do rio Minho, com o intuito de se ligar às guerrilhas de Cabeceiras de Basto e promover a união com a coluna de Couceiro. A sua preparação e organização foi consentida por Couceiro mas não contou com o seu apoio logístico. Na noite de 6 para 7 de julho, o seu comandante, julgou oportuno atacar a Praça-Forte de Valença, convencido que havia um forte apoio monárquico no seu interior, o que não se provou. Muito naturalmente, esta incursão foi rápida e completamente derrotada e os invasores forçados a regressar à Galiza, não conseguindo, sequer, constituir uma manobra de diversão.

Uma segunda coluna, composta por cerca de duas centenas de homens, era comandada pelo capitão Sousa Dias e representava o esforço das hostes Miguelistas. No dia 7 de julho, esta coluna deveria executar um movimento de flanco sobre Chaves, a partir de Vila Verde da Raia mas foi completamente derrotada pelas forças republicanas compostas por elementos da Guarda-Fiscal reforçados com tropas de cavalaria e de artilharia de Chaves. Deste modo, o movimento de ataque principal ficou a cargo da coluna de Couceiro, composta por mais de 400 homens que, partindo das imediações de Vilar de Santos, dirigiram-se para a fronteira portuguesa que cruzaram em Sendim.

A partir daqui, a coluna iniciou um movimento em direção a Vilar de Perdizes, não sem antes intimar a guarnição de Montalegre à rendição. Esta, julgando-se ameaçada, retira da vila e solicita reforços urgentes ao comandante militar de Chaves. Assim, na noite de 7 para 8 de julho, uma coluna de reforço, bem armada e municiada, é enviada para Sapiãos, com o intuito de travar a progressão da coluna monárquica. Deste modo, quando na manhã do dia 8 as forças Couceiristas atacaram Chaves, apanharam de surpresa as poucas tropas que ali permaneceram nos quartéis. Apesar da superioridade numérica, os monárquicos não conseguiram vencer a feroz oposição defensiva republicana e, após várias horas, o combate foi decidido aquando do regresso a Chaves das tropas que haviam sido enviadas para defender Montalegre (Figura 5).

Com o avolumar das baixas e a diminuição das munições, Couceiro decidiu bater em retirada em direção à fronteira. Contudo, não era sua intensão imediata internar-se, mais uma vez, na Galiza, mas sim reunir-se com a coluna de Sousa Dias para, de forma combinada, juntarem-se às guerrilhas de Cabeceiras de Basto de modo a sublevarem a província do Minho. No entanto, e tal como da primeira vez, o País não reagiu. A isto, somavam-se as constantes deserções que desmoralizavam até os mais fiéis seguidores da causa monárquica. Deste modo, após alguns dias a deambular pela linha de fronteira, entre o vale do Tâmega e a serra do Larouco, a 13 de julho de 1912 a coluna couceirista internava-se na Galiza sob apertada vigilância da Guardia Civil ${ }^{48}$.

Sobre esta incursão, o jornal A Capital publicou um primeiro mapa no dia 9 de julho, que mostrava a região entre Chaves e Braga, onde decorriam os acontecimentos (Figura 6). A 13 de julho, o mesmo periódico publicava um segundo mapa, intitulado "Croquis do Campo de Operações”, figurando, numa escala mais detalhada, o terreno compreendido entre Cha-

48. A. Coimbra, Paiva Couceiro..., op. cit., 107-112. 


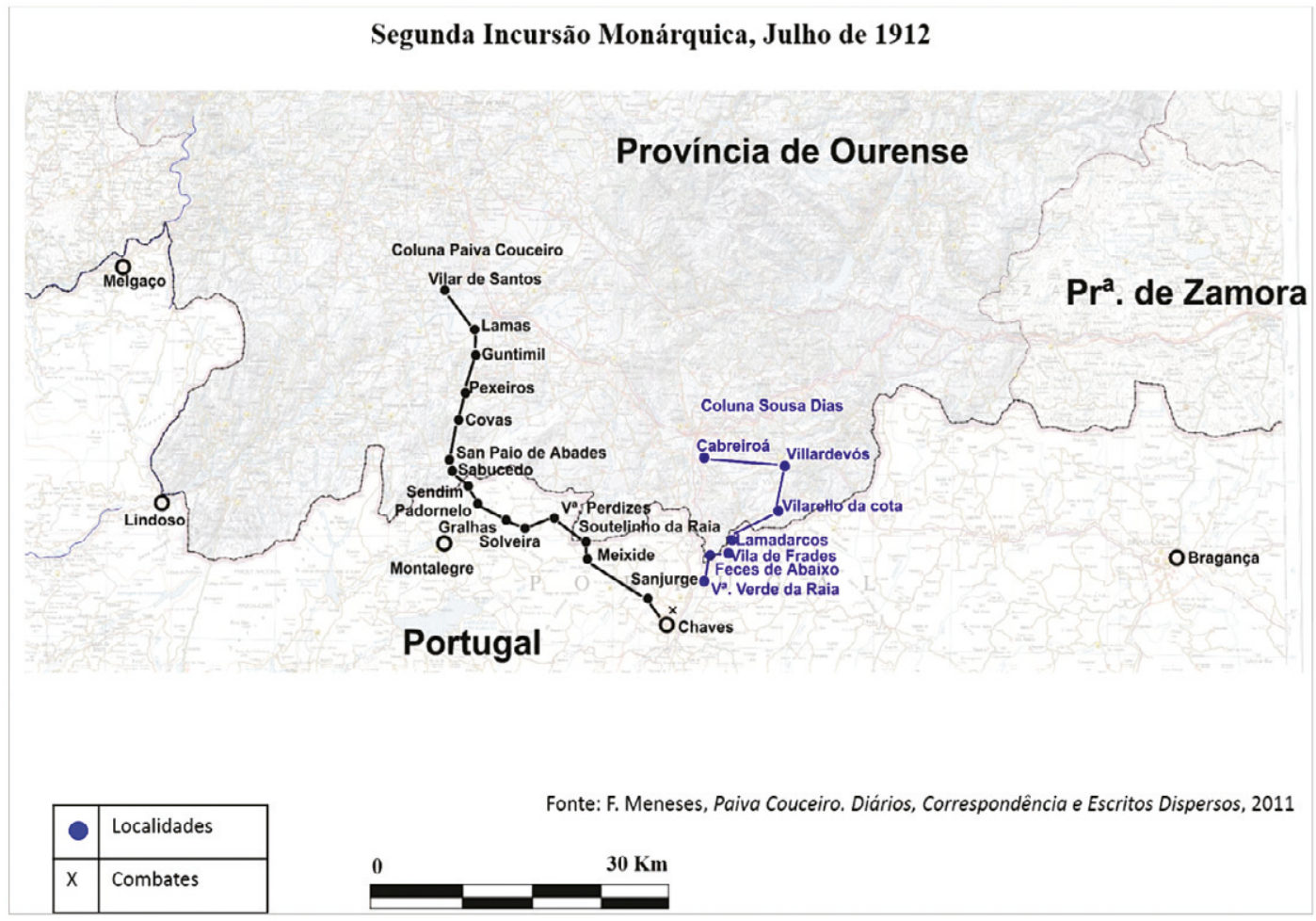

Figura 5: Itinerário da segunda incursão monárquica, com a reconstituição do movimento das colunas de Paiva Couceiro e de Sousa Dias.

ves e a fronteira. Aqui também se dava conta da evolução dos acontecimentos, desde o ataque monárquico à perseguição final (Figura 7).

Terminava, desta forma, a segunda tentativa de sublevação monárquica a partir da Galiza. Com algumas exceções, as autoridades espanholas conseguiram desarmar os monárquicos e permitir a sua partida para o exílio ou o seu internamento em campos de detenção localizados bem longe da raia. Contudo, a "causa monárquica" não esmoreceu.

A partir de finais de 1917, a chegada ao Poder por parte de forças políticas conservadoras lideradas por Sidónio Pais, que se tornou Presidente da República, inaugurou um período conhecido como "República Nova". Foi permitido o regresso de muitos exilados políticos, entre os quais o próprio Couceiro, a quem foram concedidos diversos indultos.

Este governo durou um pouco mais de um ano e terminou de forma trágica, com o assassinato do Presidente, seguindo-se uma série de movimentações políticas que levaram à formação de juntas militares, algumas das quais sublevadas. Aproveitando este ambiente de instabilidade, a partir da cidade do Porto, os monárquicos, de novo comandados por Paiva 


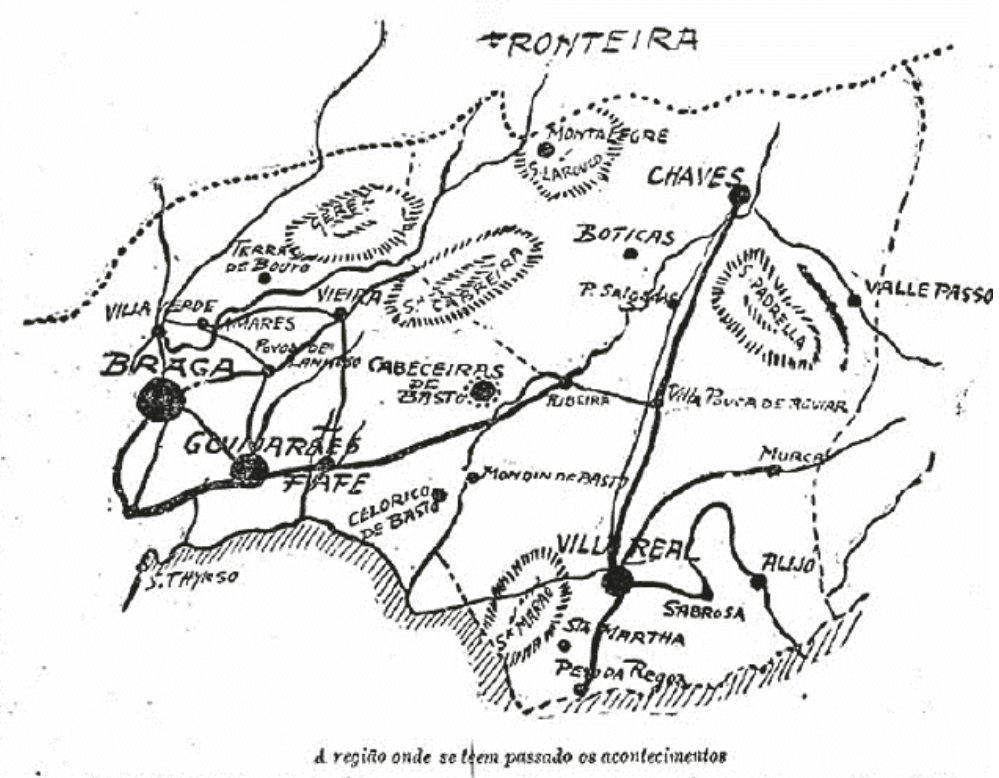

Figura 6. Mapa para a contextualização dos acontecimentos relativos à sublevação monárquica. Fonte: A Capital, 6 de julho de 1912.

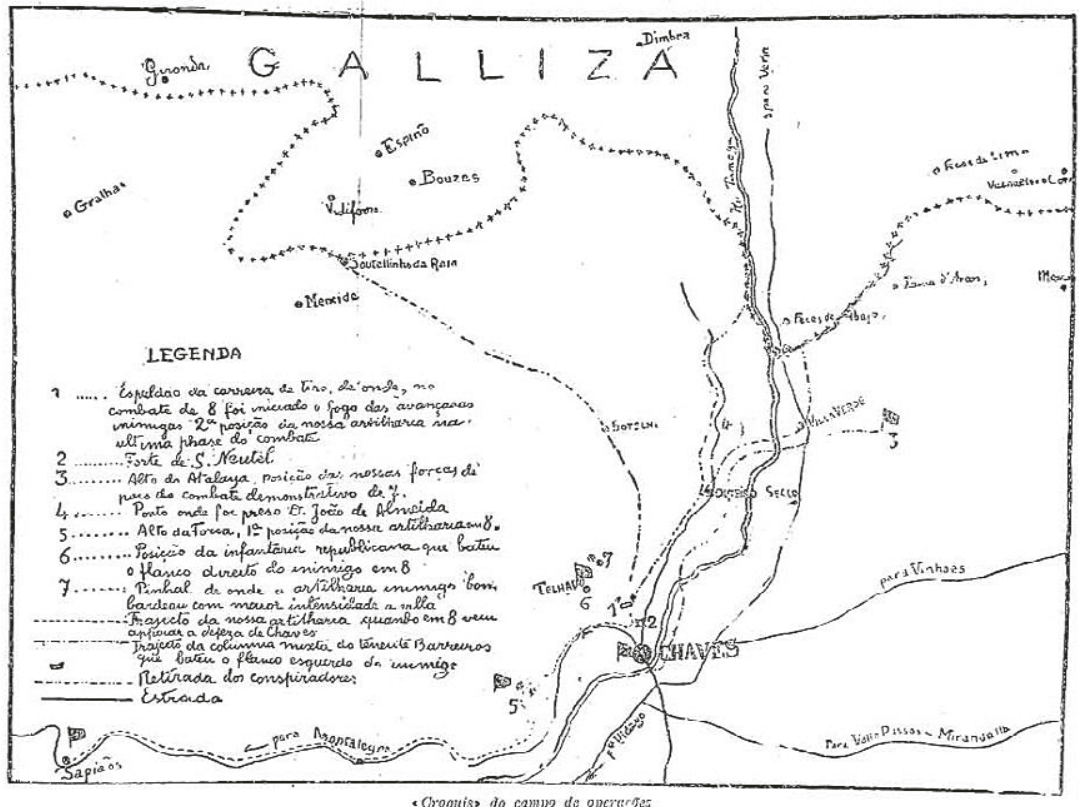

Figura 7. Mapa ilustrativo dos principais movimentos militares e dos combates travados na região de Chaves, nos dias 7 e 8 de julho de 1912, na perspetiva dos republicanos. Fonte: A Capital, 13 de julho de 1912. 
Couceiro, proclamaram a Monarquia ${ }^{49}$. Mas a efémera "Monarquia do Norte", como ficou conhecida, resistiu menos de um mês ao contra-ataque republicano, forçando os monárquicos a um novo exílio na Galiza onde, durante algum tempo, mantiveram atividades conspirativas e subversivas ${ }^{50}$.

\section{Conclusão}

As incursões monárquicas constituíram o último grande conflito fronteiriço em Portugal, ainda que na forma de guerra civil e não para enfrentar uma ameaça de invasão estrangeira.

O contingente de exilados monárquicos portugueses no sul da Galiza só conseguiu estabelecer as suas bases de operações incursionistas graças ao apoio concedido pelas diferentes autoridades espanholas: um apoio tácito vindo de Madrid, tanto da Corte como de muitos setores do Governo, e um apoio local mais efetivo, da parte dos caciques, assim como da parte dos membros da aristocracia e do clero e, sobretudo, da população. Só desta forma foi possível acolher, alimentar e armar algumas centenas de homens durante tantos meses, ao mesmo tempo que as pressões diplomáticas ameaçavam tornar o caso um incidente diplomático internacional ${ }^{51}$.

A ameaça contrarrevolucionária interna, respaldada pelo inimigo de sempre, fez, por um lado, recrudescer o "Perigo Espanhol" 52 e, por outro lado, serviu de fator de união entre republicanos, sendo aproveitado pela propaganda oficial para reforçar as instituições do regime e doutrinar as populações.

Os mapas publicados nos diferentes periódicos, nos cartazes e nos postais, constituíram uma forma eficaz de localizar e de contextualizar os acontecimentos, numa altura em que o fotojornalismo se desenvolvia em Portugal. Apesar da atenção que mereceram na sua época, as Incursões Monárquicas, e em particular a sua análise geográfica, não constitui um tema muito considerado na historiografia atual, geralmente não merecendo mais do que uma breve referência. Assim, não constitui surpresa verificar que a sua reconstituição cartográfica é, geralmente, pouco cuidada e rigorosa ${ }^{53}$.

49. R. Martins, A Monarquia do Norte, Lisboa, 1922; H. Silva, Monarquia do Norte - 1919, Lisboa, 2008.

50. A. Comesaña Paz, "Dios, patria, rey y.. contrabando. Tras las huellas del exilio monárquico portugués en España después de la derrota de la Monarquía del Norte (1919)", Espacio, tiempo y Forma, V, 25, 2013, 235-274.

51. H. Torre Gómez, Conspiração..., op. cit., 206.

52. Sobre o "Perigo Espanhol", ver H. Torre Gómez, Do Perigo Espanhol à Amizade Peninsular - PortugalEspanha, 1919-1930, Lisboa, 1985.

53. Levamos em consideração a análise de algumas das mais recentes obras de referência sobre este assunto que incluem reconstituições cartográficas: S. Enrich Marcet, 2004, p. 11, 41, 253, 302, 303, 307, 326 e 363; V. Valente, 2006 e J. Pinto, 2010, p. 134-135. 